Rado L. Lencek

CDU 808.63-087-25-563.2(497.12-15)

Columbia University in the City of New York

U. S. A.

\title{
ON THE USE OF THE GERUND IN -Č IN THE SLOVENE DIALECTS CONTIGUOUS WITH FRIULIAN*
}

With the following observations on the use of present gerunds in Slovene, prompted by Jan Baudouin de Courtenay's Dictionary of the Ter Dialect (BdC Mss), ${ }^{1}$ and by Stanko Škerlj's Syntaxe du participe présent et du gérondif en vieil italien (Škerlj 1926), we wish to contribute to a better understanding of the evolution of the participle-gerund constructions in Slovene. The Aspect of the problem raised in the discussion links, symbolically as it were, the Slavic and Romance evolutions in the microcosm of little known Slavic--Rhaeto-Romance language contacts, and may be of interest to both Slovene and Friulian philology.

1.0 The general tendency of vernaculars, including those from which the modern Romance languages evolved, to restrict the use of the active participles, to dispose of their inflections and to change them into gerunds, is widely known (Meyer-Lübke 1899). Škerlj 1926 provided a well documented history of this evolution in post-classical Latin and Italian texts (Rohlfs 1949:550), and the historical grammars of Italian do not fail to stress the variety of their syntactic patterns and the ease with which predicative gerundial constructions are used in modern language (Diez 1882, Rohlfs 1949:550-555).

In contemporary Italian three such patterns are productive: (a) stare 'stand, be in the state of' \pm gerund, e.g. , sto mangiando ' $I$ am eating now'; (b) verbs of motion (andare 'go', venire 'come', mandare 'send') \pm gerund, e.g., andar pensando 'go deliberating', venir gridando 'come shouting', mandare pregando 'send requesting'; and (c) verbs of physical perception (vedere 'see', udire 'hear', trovare 'find') I gerund, e.g. ti vedo correndo 'I see you running', lo trovai giocando 'I found him playing'. Some of these patterns are commonly used in the individual languages of the entire family of Romance tongues, although their frequency and productivity may vary from language to language. The same is true of the Rhaeto-Romance languages, in particular of patterns (b) and (c). They abound in older texts translated from Latin and Italian; in general, they are much less frequent in vernaculars as well as in the modern texts of individual languages (Gartner 1883, Augustin 1903, Velleman 1924, Rohlfs 1975, Gregor 1975).

In Friulian, gerunds (better: gerundial participles, Gregor 1975:131), e.g. , puartant 'carrying', vàint 'crying', lant 'going', ciantant 'singing', presumably are going through a similar evolution. A comparison of Friulian texts spanning

* I would like to express my appreciation to Robert Austerlitz for his comments on an earlier version of this paper. 
a period of one hundred years seems to corroborate Gartner's observation that their usage has been gradually decreasing in Rhaeto-Romance (Gartner 1883:121). E.g., in FRIULIAN 1860: Ma viodînd, che lu vint al ère gajàrd, si spaurì: e scommencand a là sott, al cijula dịsind: Signòr sàlvimi! 'But seeing the win $\bar{d}$, he became afraid, and beginning to sink, he cried out, saying: Lord, save me! Mt. XIV 30; vs. FRIULIAN 1970: ... a viodint ch'al scomenze a lâ sot, al urle: Signòr, sàlvimi! Cf. in ITALIAN 1818: Ma osservando, che il vento era gagliardo, s'impauri, e principiando a sommergersi, grido, e disse: Signore, salvami! In CSS: JERE-PECJAK-SNOJ 1948: Ko pa je videl silni veter, se je zbal; začel se je potapljati in je zavpil: Gospod, reši me!

On the other hand, cursory inspection of a few modern Friulian texts suggests that the Friulian gerundial patterns and their frequency very often parallel the Italian usage. E.g., in folksongs: Tornant de l'Ungiarie/la ciatar sul lavador ... 'Returning from Hungarian lands/I met her at the fountain ...'; or in vernacular in general: Al va pes ostariis, ciantant strofetis 'He goes round the taverns, singing songs'; Al restà di clap viodint che erin sparis i soi bragons 'He was dumbfounded on seeing that his trousers had disappeared' (Gregor 1975:131); or even in modern prose: Linde 'e viveve per sa cont, lavorant plui che podeve 'Linda lived her own life, working as hard as she could' (A. Cantoni; Gregor 1975:334). In constructions with verbs of perception (our type c), on the other hand, the use of an $a+$ inf., or of a tal + inf. pattern seems to dominate the usage in Friulian today, at least in the variety of language in Gregor 1975, or in the dialect of my informant. ${ }^{2}$ E.g.: Tal lâ vie, un di chei doi viandanz al disè ... 'In going away, one of those two travellers said ...'; La vin cialade a jevâsi 'We watched her getting up'; sintinmi a ciacarâa 'hearing me talk'. It was impossible to establish at this stage of our investigation to what extent the gerundial constructions of our type $\underline{c}$ might have been part of vernacular usage in the recent past, and which Friulian dialects have it to this day.

2.0 The transformation of active participles in Slavic languages underwent a similar process. The evolution of this class of verbal-nominal forms was imposed by the syntactic functions they performed in a sentence: When used appositively, the participles mostly intensified their verbal grammatical categories and became gerunds (e.g. in Slovene the type: govorimo stojéč 'we speak standing'); when used attributively, the participles lost their verbal categories and became adjectives (e.g. in Slovene the type: stojèc ovratnik 'stand-up collar'); when used as part of the predicate in a sentence (e.g. in Slovene the type: biti stojecc 'be standing', or vidim ga stojéč(ega) 'I see him standing'), they were substituted either by infinitives (vidim ga stati 'I see him standing') or by subordinate clauses (vidim ga, da/kako stoji 'I see him standing') (Nahtigal 1952:229-230). Slavic vernaculars went even further in this evolution: they abolished the attributive use of participles altogether. In the literary languages, on the other hand, the inflected participles were rehabilitated and became part of the nominal systems (Vaillant 1958:548-549).

The CSS still knows two forms of the present active participle, one in $-\dot{e} /-j e$, and one in -c.. 3 Both forms are used in predicative function as noninflected com- 
plements to the predicate. Present active participles used in this function tend optimally to preserve their verbal categories of aspect, voice, concord; and they can be modified by an adverb. E. g.: Godrnjaje je odšel 'He left grumbling'. Stoječ smo govorili 'We talked standing'; or in poetry: "Pod njim se mègle temno sive / valé čez vrte, trate, njive, / grmeč groznó, preteč strašnó. / Pred selsko kočico klečé / otroci, starčki in žené, / z boječim, solznatim očesom, / k oblačnim, mračnim zro nebesom / glasno ihteč, / k Bogu moleč"l. (S. Gregorčič, "Oljki"); or: "Pozval nato krdela sem 7 in prišla so hrumeč, / zaznamoval jim čela sem / preteč in pa svareč (S. Gregorčič, "V pepelnični noči"). The present participles in such and similar functions are used as predicative adverbs, corresponding to the gerunds of the Romance languages. For such a form employed in predicative function we use the term present gerund. 4

2.1 It has been shown that in the earlier written Slovene of the sixteenth century participles and gerunds were used more broadly and more freely than they are today. They appeared more frequently not only appositively, as complements to verbs of complete predication, but also in constructions in which they were part of the predicate of verbs of incomplete predication. Several constructions of this use are known: (a) with iti 'go', and its prefixed stems; (b) with biti 'be', nehati, prestati, končati 'stop'; and most frequently, (c) with verbs of physical perception, as videti 'see', slišati 'hear', vedeti 'know', zagledati 'discover', najti 'find' (Tomšič 1955:56-66). The latter pattern, attested even today in some Westernmost Slovene dialects (see our 4.0), is of particular interest to us. Its usage agrees with that found in older stages of other Slavic languages. This refutes F. Metelko's claim that the verbs of perception + gerund pattern in Slovene texts must have been borrowed from Latin (Metelko 1825: 232). Numerous examples of this usage with the common Slavic verbs *vidéti 'see', *slyšati 'hear', *obrĕsti 'find', and their equivalents in Old Russian, Old Polish, Old Czech, and Old Serbian texts, as well as occasionally in the earlier Russian vernacular (Buslaev 1959:535-537; Potebnja 1958:310-318; Belic 1965:192), suggest that this pattern evolved relatively late in already differentiated Slavic languages, might have undergone parallel evolutions, and developed independently of outside impulses.

At first two types of constructions competed with the predicative gerund use in this particular pattern in Slovene: the gerundial form was substituted either by a relative clause or by an infinitive form. It is interesting that these two patterns almost entirely displaced and superseded gerundial constructions with verbs of perception already in the last quarter of the sixteenth century. E. g.:

TRUBAR 1557: kadar on no plazheiozh uidi (Jn. XI 33) 'when Jesus ... saw her weeping'; DALMATIN 1584: kadar je lesus njo vidil, de fe je plakala; JEREPEČJAK-SNOJ 1948: ko je tedaj Jezus videl, da joka.

TRUBAR 1578: nei prestala kushuiozh moie Noge (Lk. VII 45) '(she) has not ceased to kiss My feet'; DALMATIN 1584: nej nehala moih nug kufhovati; JERE-PEČJAK-SNOJ 1948: ta pa ni nehala ... poljubljati mojih nog. 
TRUBAR 1582: de tim ludem ne bosh vidil fe po(tiozh (Mt. VI 18)' so that you may not be seen fasting by men'; DALMATIN 1584: de (e nebo Ludem vidilo, de fe poftifh; JERE-PEČJAK-SNOJ 1948: da ne pokažeś ljudem, da se postiš.

TRUBAR 1564: Natv ta prydigar dershozh nih obeyu roke ukupe ima letaku govoriti; Literary Slovene: Nato pridigar, držeč sklenjene njune roke, reče tako-le 'then the preacher, joining their hands, says thus'.

A third construction developed later, although still during the sixteenth century: the predicative gerund was once again substituted by an inflected participle pattern; the construction was introduced very probably in immitation of the Latin syntactic agreement of the participle with its substantive. E.g.:

DALMATIN 1584: Inu Ioannes je vidil Boshjiga Duhá, raunu kakor eniga Goloba doli gredozh, inu nad njega prideozh (Mt. III 16) 'he saw the Spirit of God descending as a dove, and coming upon Him'; LATIN: et vidit Spiritum Dei descendentem sicut columbam, et venientem super se. In a translation quoted by $\mathrm{Me}$ telko 1825: 232: On je videl duha božjiga kakor eniga goloba dole gredeočega, ino nad njega prideočega; JERE-PEČJAK-SNOJ 1948: in je videl božjega Duha, ki se je kakor golob spuščal navzdol in prihajal nadenj.

3.0 It is difficult to judge how much the gerundial forms of written texts of any period represent the patterns of gerundial usage in slovene as such. It is known that such a use presupposes a complex sentence structure which is not typical of everyday vernacular, whereas the available data from the dialects are neither numerous nor sufficiently representative. To a certain degree individual literary texts may contain the vernacular patterns of their creators' dialects; thus S. Gregorčič's examples (see our 2.0), supply useful supporting data on the frequency and extent of gerundial usage in the Western Slovene speech area. Unfortunately, even such texts are not numerous in Slovene literature and their gerundial forms are not always free of possible stylizations.

Paradoxically, the only systematic collection of data on the predicative usage of present gerunds in Slovene comes from dialects which underwent a relatively strong non-Slavic linguistic influence. Thanks to the dialectal collections of $\mathrm{J}$. Baudouin de Courtenay, we possess today a unique inventory of gerundial forms and structures recorded in some Westernmost Slovene dialects, very well known not only for their openness to Romance and Rhaeto-Romance innovations, but also for their persistent continuance of some old archaisms.

The data to which we refer are from the Ter and Rezija dialects of. Venetian Slovenia. Some of our examples are taken from the folk-narratives which Baudouin de Courtenay published in BdC 1895 and BdC 1904; most of our patterns of gerund usage, however, are drawn from his unpublished Dictionary of the Ter Dialect (BdC Mss), an extremely valuable glossary with rich phonetical, morphological and syntactical information on the speech of his Terskie slavjane. To allow a comparison of the usage of the same patterns during a span of one hundred years, some recently recorded examples from the same area are also used in our analysis (Merkù 1976). 
3.1 Examples. 5

(1) Aṇ je šàl jö́čajoć; Ger.: Er ging weinend (V Bili, S. Giorgio) [BdC 1895:16].

(2) Spíjeoć je dušàl moj $a_{\mathrm{i}}$ ík; Ger.: Trinkend ist mein Freund angekommen (V Bili, S. Giorgio) [BdC 1895:35].

(3) Na trèšt, na jí lažộ́; Ger.: Sie (die Zeige) ist traurig, sie frisst liegend (Ravanca, Prato di Resia) [BdC 1895:178].

(4) Ki su-začẹle čarjéšńe zdrjẹttb, kẻ to-ba ta-párwa šperảnča, so jûdjb začẹlb živítb, čarjéšńe berọć. Rus.: Kogda čerešni načali sozrevat', tak kak èto byla pervaja nadežda, ljudi načali pitat'sja, sobiraja čerešni. (Viškorša, Monteaperto) [BdC 1904:181].

(5) Te rád za-nancwôj, nì-mę-ûsta-bolẹ ćakarọć, ttkàj nâs, cjệw-dân. Rus. : Dovol'no dlja segodnjašnego večera; rot bolit u menja, kogda ja govorju, kak segodnja, celyj den'. (Viškorša, Monteaperto) [BdC 1904:261].

(6) Zầt dan-dân, kar je-bî stự koštjonọć, je wstù-wőn zjútra đwộda, ȩ-viljệzuw wôna pijôw. Rus.: Zatem $\mathrm{v}$ odin den', kogda emu nadoelo ssorit' sja, on vstal rano utrom i vyšel na kryl'co. (Viškorša, Monteaperto) [BdC 1904:315] [koštjonọć 'quarelling', cf. It. questione=lite, contesa].

(7) A ce-tę dệš, to-mầ kuj tầ-wonề zmarznuwât, mrầ čâkoć. Rus.: Esli že dožd', togda prixoditsja tol'ko zjabnut' na dvore, dožidajas' moroza. (Karnahta, Cornappo) [BdC 1904:412].

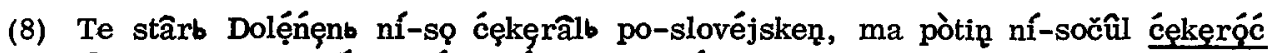
lâške, sq-sę-nazábblb ceękęrát po-slovéjsken. Rus.: Starye Dolenjane govorili po-slovenski, no posle ony slyšali reč' furlanskuju i zabyli govorit' po-slovenski. (Černjeja, Cergneu) [BdC 1904:719].

(9) Anzzát téle Láx ę-šủ blešteçmaje fór-po-bórze. Rus.: I togda ètot Furlan šel po dvore rugajas'. (Mažerole, Masarolis) [BdC 1904:794].

(10) Sănṇ-jo-vídu smejẹ. Rus. : Ja videl ee smejavšejsja. (Mažerole, Maserolis) [BdC 1904:888].

(11) berơóc 'reading': berọoć drufọ líbrinę, It. : leggendo altri libri;

(12) bútuć 'fighting': sbm vídu bútuć dwa móža (kb su se bútalb);

(13) ćakarọćc 'speaking', inf. ćakarati, Fri.: ciacarâ: są čóu ćakarọoc, It.: ho sentito favellare; są čóu ćakarọć nágra móža (nápra sínu, nu xcécér, nú ženú); se čuje ćakarọ́ć, It. : si sente parlare (Sedile, Sedilis); cekęróć=rožinọćć (inf.: rožinátb);

(14) čakơć 'waiting';

(15) ćantọć 'singing' [inf. 'ćantáti, Fri.: ciantâ] ; smo šlb ćantọćc=pojọcó (Černjeja, Cergneu);

(16) čiésoć 'combing' (inf. : česátb): sbm vídu čiésoć; 
(17) diẻloć díluć 'doing' (inf. : diélatb): nú ne kapíjejo, kno xódite díluć, Rus.: oni ne ponimajut, čto vy delaete (Sedile, Sedilis);

(18) fodọć 'playing' (inf.: góstb, It.: suonare): sbn čú godọć;

(19) fráboć 'raking': sל̀n fa vídu gráboć;

(20) réjoćc 'warming' (inf.: se riétb 'to warm oneself'): sa a vídıu se réjọc (Črnjeja, Cergneu);

(21) rredę 'walking' gerundio: sam vídu redẹ (Čenebola, Canebola);

(22) xúkọc 'blowing': sĭn fa čú / vídu xúkọc (Platišča, Platischis);

(23) jamanéikuć 'moaning' (inf.: jamaneikátb=stọ́katb) [from Germ. interjection je, jemine 'good gracious'] : š́n fa čú jamanéikuć;

(24) jedọc 'eating': si vídala jedộc no žęnö?

(25) jókoć ujōkuć 'crying': si vídou jókọć? jókuć; san ga vídou jókuć (Tipana, Taipana); š̆n ga vídu jộkuć;

(26) . klọć 'cursing' (It. : bestemmiare): sân ya vídzu klọć (Tipana, Taipana);

(27) kópọc 'digging', (inf. kopátb);

(28) korọć 'disputing': sbm vídu korọć dwa móža (kơ su sẹ korílb);

(29) moleéc 'praying' [inf. molítb];

(30) nesơó 'carrying': sbgga víduu nesọćc, Rus. : ja videl ego nesuščim (Sedile, Sedilis);

(31) pazdẹć 'farting': šnn ła čú pazdẹć (Platišča, Platischis);

(32) péjoć 'conveying', inf. pejátb It. : transportare con carro: są a vídsu pejọć (Černjeja, Cergneu);

(33) píxoć 'blowing': sb̉n ga čú / vídu píxọć (Platišča, Platischis);

(34) pijọćc 'drinking': si vídala pijọóc no žęnő?

(35) písoćc písuć 'writing', It.: scrivendo: łremó po pọtb písọć (Tipana, Taipana); ș̆ a víduu píñuć (Sedile, Sedilis);

(36) plákuć 'crying': șą ju vídu plákuć, Rus.: ja ee videl plačuščeju;

(37) pláwoć 'swimming' (inf. : pláwatb): sin ya vídu pláwóc;

(38) pléšoć 'dancing': sñ qua vídu pléšọć, sn̆ jo vídu pléšọć, sbm vídu pléšọc;

(39) pojọcóćantọćc 'singing': smo šlb" pojọć (Černjeja, Cergneu);

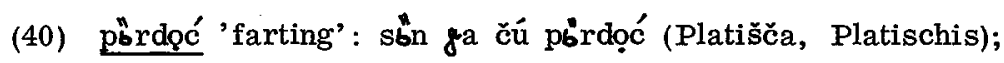

(41) rožinóćććekerọć 'speaking' (inf. : rožinátb) cf. (13);

(42) siérjóc, nu sérjuć 'shitting': š̉n ga vídu siérjọć (Platišča, Platischis), să ga vídzu sérjuć; 
(43) se smejóćcu sẹ smęjoć 'laughing' : si vídala sȩ smẹjoć no žęnỏ? š̋n ga vídu sẹ smejọć;

(44) stojẹć 'standing': ćbmó ćakarátb, stojẹć tlè, náše réči (Sedile, Sedilis);

(45) stộkuć 'moaning' (înf. : stọokatb): sb̌n ga čú stộkuć;

(46) svífoć 'hissing' (inf.: svijútb, It.: siffiare): stn fa čú svigọć (Platišča, Platischis);

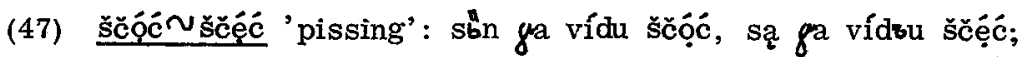

(48) ubíwọc 'killing' (inf.: ubiwátb): sőn ga vídu ubíwọć, It. : lo ho veduto amazzare;

(49) umíwóc 'washing' (inf.: umiwátb): sb̆n ya vídu umíwọć;

(50) wékqćn wékuć ' crying' (inf. : wékatb): si vídala wékọć nö žęnỏ? sb̆n ga

(51) veliezúọć 'coming out' inf.: viliéstb: są ga vídøu veliezúọć (Černjeja, Cergneu) $[(11)-(51)$ from BdC Mss].

(52) In te, $\mathrm{k}^{\prime}$ bo šíndik, te $\mathrm{k}^{\prime}$ bo vídeu te pŕvi sónce ustájoć. Sónce ustájoć te pívi. It.: E sarà sindaco colui che vedrà per primo il sole sorgere (Platišča, Platischis) [Merkù 1976:322].

(53) Alóra e on se stufou čákoć ta-par onju. It.: Lui si stufava di aspettare attorno al fuoco (Bardo, Lusevera) [Merkù 1976:360].

(54) ... far o e mrou jíte kíši ćoteoć. It. : ... e il prete dovette ritornare a casa zoppicando (Njivica, Vedronza) [Merkù 1976:374].

(55) Alore télé e wzeu oré fárja ta-na pléća e zat e soun to tale rotéć e to-u túrme, $\mathrm{ka}$ e miesoun te kulíne ... It.: Perciò quello si caricò il prete sulle spalle: a quell'altro che faceva rumore nella torre mescolando le noci (disse): ... (Njivica, Vedronza) [Merkù 1976:374].

(56) ... na sveta Marija hódi protejuúć (It. : cammina proteggendoci) (Bardo, Lusevera) [Merkù 1976:364].

(57) pedadúć (It.: 'dando pedate', inf.: pedadáti, from pedata 'kick') (Bardo, Lusevera) [Merkù 1976:364].

\subsection{Morphology and syntactic patterns of the recorded usage}

4.1 As in contemporary standard slovene, one finds in our Corpus two forms of present gerunds: a form in $-\underline{e} /-j e$, cf. examples (9)-(10), (21); and a form in -č. Both forms appear only from imperfective verbs, though one -c gerund from a perfective verb also seems to occur; viz.: spíjeoc (2). The desinence

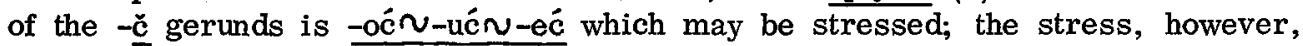
is not yet generalized on its vowel as in CSS; the situation resembles the state of affairs in sixteenth century Slovene texts (Nahtigal 1952:234; Ramovš 1952: 146-147). The distribution of -oć and -éc seems to be the same as in contempo- 
rary standard Slovene: -ec is limited to verb of classes III/2 and IV, with one exception: koróć (28), and one alternative formation: ščóć ščéć (47). The desinence -uć in native verbs occurs only when uñstressed, e.g. , bútuć (12), jókuć $\sim$ jókoć $(25)$, písućc $\sim$ písọc $(35)$, wéksuć wwékoć $(50)$; in the new borrowed stems also under stress, e.g.: protejúc (56), pedadúc (57), which clearly indicates a relative chronology of this formation: an $\underline{0}>\mathbf{u}$ vowel reduction in unstressed syllable must have preceded the morphologization of stress in these forms. The formation of a few gerunds in $-\underline{\dot{c}}$ is transparent: 3 rd pl. pres. $t . \pm-\underline{\dot{c}}$, e.g. , písoć (35), beróć (11), elsewhere it is analogical, e.g., diéloć (17), jốkoć (25), coteóc (54), cakarọć (13), spíjeoć (2); once the gerund is based on the infinitive stem, klọc $(26)$. The terminal -ćc is always (ć), in Baudouin de Courtenay's notation: $/ c^{\prime} /$ in free variation with (t') or (t's), e.g. : cakaróćc $\sim t^{\prime}$ akarót' $\sim t^{\prime}$ 'akarót's (BdC Mss).

4.2 Essentially three types of syntactic patterns characterize the usage of -č gerunds in our Corpus.

Type One: Gerund is Linked to the Subject of the Sentence.

Examples:

(a) añ je šàl jóčajoć (1)

(b) sọ júdjb začẹlb živítb, čarjéšńe berọć (4)

(c) smo šslí pojọ́ć (15)

(d) ćbmó ćakarátb, stojẹcé tlè, náše réči (44)

(e) alóra e on se stufou čákoć ta-par onju (53).

Our examples (1)-(7), (15), (35), (39), (44), (53)-(54), (56)-(57) belong to this type.

In traditional terms, the function of gerundial forms of our Type One is appositional. The action expressed by the gerund relates to the subject; it accompanies the predicate of the sentence which is an intransitive verb; in a number of cases, this verb is a verb of motion, Sle.: iti, hoditi 'go'; cf. our examples (1), (2), (15), (35), (39), (54), (56), (57). This pattern represents the most frequent use of gerunds in the Slovene dialects, and the "adverbial usage of the present active participles" in the norm of the CSS (Breznik 1934:143); it may be typified by the following syntactic scheme:

$\frac{\text { Otroci so hodili. }}{\text { Otroci so peli. }}$ Otroci so hodili pojoč.

This pattern is all-Slavic (Miklosich 1883, Potebnja 1958), and may be paralleled with its usage in Romance languages, including Friulian (Škerlj 1926).

Type Two: Gerund is the Main Object of the Sentence.

Examples: 
(f) sbm vídu bưtuć dwa móža (12)

(g) są čou cakarọć nu xcéér (13)

(h) son čú gọdọć (18)

(i) siǹ vídu pléšọc \& sñ jo vídu pléšọć (38)

(j) si vídala se sméjoć no žęnō? (43)

(k) šíndik ... bo vídeu te pŕvi sónce ustájoć(52).

Our examples (8), (12)-(13), (16), (18)-(20), (22)-(26), (28), (30)-(38), (40)-(43), (45)-(52) belong to this type. For CSS, this type could be hypotetically construed as * Slišal sem otroke pojoč. Note that all gerundial forms used in this type in our dialects complement verbs of physical perception.

In traditional terms, the function of gerundial forms of our Type Two is narrowly predicative. At one point of the evolution of this construction, the action expressed by the participle was conceived as a complement to a verb of perception; the participle (later gerund) expressed the state as a verbal action, i.e., as an object of perception. Thus in two simple constructions of our examples (i) and (h), exactly as in the sixteenth century Slovene texts, gerundial forms are used as complements (direct objects) to verbs of perception. E. g. :

TER DIALECTS: shỳ vídu pléšoć (38), şn čú yodóćć (18), DALMATIN 1584: fim slifhal od tebe praveozh Gen XLI 15, CSS: sem videl plesati, sem slišal gosti, sem slišal praviti o tebi.

In most examples of our Corpus, however, the action expressed by the gerund, appears also with its own complement (Potebnja 1958:310 calls it a "second accusative" object); e.g. , sñ jo vídu pléšocé (38), or sbm vídu bútuć dwa móža (12), with a vernacular syntactic variation: sьm vídu dwa móža $\mathrm{kb}$ su se bútalb (BdC Mss), which corresponds to the type of relative clause used in CSS in lieu of infinitives. E.g.:

TRUBAR 1557: kadar on no plazheozh uidi (Jn. XI 33); with inf.: ko jo je tedaj Jezus videl jokati se; with relative clause in

DALMATIN 1584: kadar je Jezus njo vidil, de (e je plakala; JERE-PEČJAK-SNOJ 1948: ko jo je tedaj Jezus videl, da joka.

One of the characteristics of the syntactic patterns with the verbs of perception in modern Slovene is that they may have passive transformations (Breznik 1934: 139), e.g.: Slišal sem peti, vs. Peti je bilo slišati; and: Slišal sem peti otroke, vs. Peti je bilo slišati otroke. Such passive transformations clearly indicate the function of the infinitive (or earlier gerund), and of the subordinate complement (otroke) in the sentence. No such transformation, of course, is possible within our syntactic pattern Type One.

Type Three: Gerund in a Loan Translation of a Non-Slovene Idiom. The only example: 
(1) nú ne kapíjẹjo, ku্রo xódite díluć (17).

The idiom kno xódite díluć, Rus. : čto vy delaete, Sle. : kaj počenjate 'what are you doing', is a simple loan translation of the Italian andar facendo qualche cosa 'to be doing something', with an exact element by element reproduction of the model. The finite verb in andate facendo represents an auxiliary, which in Italian intensifies the durative aspect of the predicate expressed with gerund (Škerlj 1926:205). This pattern is frequent in Italian, Friulian, and Rhaeto-Romance; it is interesting that it only recently appears in the records of the Ter dialects.

5.0 A limited surface comparison of the similarities in three basic patterns of the present gerund usage in the dialects on both sides of the Romance - Slavic linguistic boundary and their broader linguistic environments suggests the following observations:

1. Two basic syntactic patterns of the present gerund in Type. Two), recorded in Western Slovene dialects, seem to mirror the Slavic gerundial patterns as known from the structure of sixteenth century written Slovene. One marginal syntactic pattern of the idiomatic use of the present gerund in -č (our Type Three) represents a direct loan translation of an idiom from Italian and Friulian.

2. Since in Rhaeto-Romance and Italian in general the frequency of gerundial forms seems to be higher and the variety of their syntactic patterns greater and more typical for these two dialectal groups than for Slavic, the existence of what one may call "the gerundial grammatical habit" in Western Slovene dialects may easily be understood as a result of direct grammatical interference stemming from the contact with Romance languages. The observed grammatical interference, however, seems to represent a particular case of "mixing of the morphologies" of the contact languages, which should be qualified.

At one point of their evolution, two languages, A in B, in contact, may possess some identical grammatical categories, equivalent morphemes, and analogous patterns. In its subsequent individual evolution, one of these two languages, e.g. language B, may lose some of these patterns, whereas some of its dialects which are in contact with language $A$ may retain them. Thus, this kind of grammatical interference does not consist simply in a transfer of morphemes per se, or of their combinations in translation from language $A$ to the dialects of language $\mathrm{B}$; it concerns the maintenance or even the extension of the preexisting functions of equivalent morphemes in two languages; in our case in the dialects of Slovene on the model of the grammar of Romance languages.

\section{REFERENCES}

Augustin, H. (1903): Unterengadinische Syntax mit Berücksichtigung der Dialekte des Oberengadins und Münsterthals. Halle. 
Bajec, A., R. Kolarič, M. Rupel (1964): Slovenska slovnica. Ljubljana.

Belić, A. (1939): "Pod kojim je uslovima slovenski particip postao gerundij? Dans quelles conditions le participe slave a-t-il pris le caractère d' un gérondif invariable?" III-ème Congrès international des slavistes. Réponses aux questions. Vol. I. (Belgrade), 59-61.

---, (1965): Istorija srpskohrvatskog jezika, 2. Reči sa konjugacijom. 2nd ed. Belgrade.

Belić, A., and S. Škerlj (1939): "Postanak apsolutnih glagolskih konstrukcija (apsolutnih participa $\mathbf{i}$ apsolutnih gerundija) u slovenskim jezicima. Les origines des constructions verbales absolues (gérondif et participe absolu) dans les langues slaves". III-ème Congrès international des slavistes. Réponses aux questions. Vol. I. (Belgrade), 54-58.

Baudouin de Courtenay, J. (1895): Materialien zur südslavischen Dialektologie und Ethnographie. I. Resianische Texte, gesammelt in den J. J. 1872, 1873 und 1877, geordnet und übersetzt von J. Baudouin de Courtenay. Nebst Beilagen von Ella von Schoultz-Adaĩewski (Vorlegt am 19 August 1886). St. Petersburg.

----, (1904): Materialien zur südslavischen Dialektologie und Ethnographie. II. Sprachproben in den Mundarten der Slaven von Torre in Nordost- Italien (=Sbornik ORJaS imp. AN, vol. 78, No. 2). St. Petersburg.

---, Mss: J. Baudouin de Courtenay's manuscript collection: Materialy dlja slovarja, Terskie Slavjane. In the Archives of the AN SSSR in Leningrad, Fond 102, Opis' 1, No. 10-12.

Breznik, A. (1934): Slovenska slovnica za srednje šole. 4th ed. Celje.

Breznik, A. et al. (1940): Slovenska slownica za tretji in četrti razred srednjih in sorodnih šol. Sestavili: A. Breznik, A. Bajec, R. Kolarič, M. Rupel, A. Sovré, J. Šolar. Ljubljana.

Buslaev, F.I. (1959): Istoričeskaja grammatika russkogo jazyka. Moscow.

Diez, F. (1882): Grammatik der romanischen Sprachen, I. 5th ed. Bonn.

Gartner, T. (1883): Raetoromanische Grammatik. Heilbronn.

Gebauer, J. (1929): Historická mluvnice jazyka českẻho. Díl IV. Skladba. Prague.

Gregor, D. B. (1975): Friulan Language and Literature. New York.

Lencek, R. L. (1966): The Verb Pattern of Contemporary Standard Slovene (with an Attempt at a Generative Description of the Slovene Verb, by H. G. Lunt) (Wiesbaden), 1-131.

Leskien, A. (1914): Grammatik der Serbo-Kroatischen Sprache, I. Lautlehre, Stammbildung, Formenlehre. Heidelberg.

Marchetti, G. (1967): Lineamenti di grammatica friulana. 2nd ed. Udine.

Medved, J. (1974): Zemljevid $\mathrm{z}$ italijanskimi in slovenskimi krajevnimi imeni $\mathrm{v}$ Furlaniji, Julijski Krajini in Benečiji. Ljubljana. 
Merkù, P. (1976): Le tradizioni popolari degli Sloveni in Italia, raccolte negli anni 1965-1974. - Ljudsko izročilo Slovencev v Italiji. Zbrano v letih 1965-1974. Trieste.

Metelko, F.S. (1825): Lehrgebäude der slowenischen Sprache im Königreiche Illyrien und in den benachbaren Provinzen. Laibach (Ljubljana).

Meyer-Lübke, W. (1899): Grammatik der romanischen Sprachen, III. Syntax. Leipzig.

Miklosich, F. (1883): Vergleichende Grammatik der slavischen Sprachen, IV. Vergleichende Syntax der slavischen Sprachen. Vienna.

Milčetić, I. (1895): "Čakavština Kvarnerskih otoka". Rad JAZU, 121 (Zagreb), $92-131$.

Nahtigal, R. (1952): Slovanski jeziki. Druga popravljena in pomnožena izdaja. Ljubljana.

Potebnja, A. A. (1958): Iz zapisok po russkoj grammatike, I-II. Moscow.

Ramovš, F. (1952): Morfologija slovenskega jezika. Skripta, prirejena po predavanjih v 1. 1947/48, 1948/49. Ljubljana.

Rohlfs, G. (1949): Historische Grammatik der italienischen Sprache und ihrer Mundarten, II. Formenlehre und Syntax. Bern.

-.., (1975): Rätoromanisch: die Sonderstellung des Rätoromanischen zwischen Italienisch und Französisch. Eine kulturgeschichtliche und linguistische Einführung. Munich.

Svane, G. O. (1958): Grammatik der slowenischen Schriftsprache. Copenhagen.

Šerech, Ju. (Shevelov) (1953): Participium universale im Slavischen. Slavistica, No. 16. Winnipeg.

Škarić, B. M. (1901): "Tvorba i poraba participa (gerundija) prezenta aktiva i preterita aktiva I u čakavskoj književnosti XV. i XVI. vijeka", Nastavni vjesnik, 10 (Zagreb), 1-32.

Škerlj, S. (1926): Syntaxe du participe présent et du gérondif en vieil italien, avec une introduction sur l'emploi du participe présent et de l'ablatif du gérondif en latin. Paris.

Tomšič, F. (1955): "Poglavje iz slovenske historične sintakse", Slavistična revija, 8 (Ljubljana), 56-67.

Toporišič, J. (1967): Slovenski knjižni jezik, 3. Maribor.

Vaillant, A. (1958): Grammaire comparée des langues slaves, ㅍ. Morphologie, 2. Flexion pronominal. Lyon, Paris.

Valjavec, M. (1892): "Prinos k naglasu u (novoj) slovenštini. Naglas u participima", Rad JAZU, 110 (Zagreb), 1-109.

Velleman, A. (1924): Grammatica teoretica, pratica ed istorica della lingua ladina d'Engiandin' Ota. Vol. 2.: Verb. Zürich. 
Vondrák, W. (1928): Vergleichende slavische Grammatik, 2: Formenlehre und Syntax. 2nd ed. Göttingen.

Weinreich, U. (1953): Languages in Contact. Findings and Problems. Publications of the Linguistic Circle of New York, 1. New York.

\section{Notes}

1 The Ter dialect data in this paper are in part from Baudouin de Courtenay's manuscript collection in the Archives of the AN SSSR in Leningrad: Materialy dlja slovarja, Terskie Slavjane, Fond 102, Opis' 1, No. 10-12. We use these data with the permission of the AN SSSR. My research in the Archives in 1969 was sponsored by the American Council of Learned Societies, and the AN SSSR. I acknowledge this support with gratitude.

The abbreviations used in this paper are: $\mathrm{BdC}=$ Baudouin de Courtenay; Fri. $=$ Friulian, Ger. $=$ German, It. $=$ Italian, Rus. $=$ Russian, Sle. $=$ Slovene, CSS $=$ Contemporary Standard Slovene; Mss = manuscript; $\mathrm{m}$. = masculine, $\mathrm{f}_{\mathrm{f}}=$ feminine, $\mathrm{n} .=$ neuter; sg. $=$ singular, pl. $=$ plural; pres.t. $=$ $=$ present tense.

The references to the quotations from the Bible are from: DALMATIN 1584: Biblia, tu ie, vse svetv pismv. Wittemberg, 1584. FRIULIAN 1860: Il vangelo di s. Matteo, volgarizzato in dialetto Friuliano, dal Conte Pietro dal Pozzo. London, 1860.

FRIULIAN 1970: II vanzeli di N. S. J.C. secont Mateo (Traduzion di Meni). Udine, 1970.

GARTNER 1913: Das neue Testament. Erste Raetoromanische Uebersetzung von Jaksob Bifrun 1560. Dresden, 1913.

ITALIAN 1818: Nuovo testamento secondo la volgata, tradotto in lingua italiana da Mons. A. Martini. Livorno, 1818.

JERE-PEČJAK-SNOJ 1948: Sveto pismo nove zaveze. Evangeliji. Ed. by F. Jere, G. Pečjak, A. Snoj. Celje, 1948.

TRUBAR 1557: Ta pervi deil tiga noviga testamenta. Tübingen, 1557.

TRUBAR 1564: Cerkovna ordninga. Tübingen, 1564.

TRUBAR 1578: Postilla. Laibach (Ljubljana), 1578.

TRUBAR 1582: Ta celi novi testament. Tübingen, 1582.

The examples from TRUBAR 1557, TRUBAR 1578, and TRUBAR 1582 are quoted after Tomšič 1955; our English glosses are from: New American Standard Bible, New Testament. New York, 1963.

2 Professor A. Zamparutti, Deputy Director of the Italian Cultural Institute in New York, a native of S. Pietro al Natisone (Špeter Slovenov). I wish to thank Professor Zamparutti for this communication, as well as for giving of his time generously during our conversation on Friulian dialects.

3 The Slovene grammar books (Bajec 1964, Breznik 1934, Breznik 1940, Toporišič 1967) treat them indiscriminately as - "present participles", but differentiate their functions: attributive-adjectival vs. predicative-adverbial. Morphology imposes a number of restrictions and limitations on their formation; as 
a rule, they can be formed only from imperfective verbs (with one exception: rekoč 'saying'). The formation in -é $/-\underline{j}$ e is unproductive; its form in -é is in the CSS limited to 47 stems; it is used only predicatively. They easily pass among the adverbs, e.g., molče 'silently', glede 'regarding', hote 'willingly'. The form in -č , however, is productive in the literary standard; it has two sorts of desinences: -óč or -éć with a narrow vowel under stress, e.g., gredóč 'going', stojéč 'standing', grméč 'thundering'; the -óč/-éc represent the desinence of a short form of the 3rd pl. pres. t. -ó/-é, e.g., gredó vs. stojé, plus -č. When used predicatively, these forms do not change; prosodically they are marked with a generalized long rising accent. When used attributively, these forms appear with a terminal adjectival gender-number suffix; the m.sg. form of such a participle normally appears with a short accent, e.g., grmèč m.sg., vs. grméča f. sg., grméči m.pl (Lencek 1966:107). The attributive-adjectival forms as a rule form adverbs in -e, e.g., grméče. The - c forms in attributive use retain adjectival agreement with the substantive, e.g., pojoč fant 'a singing young man', speča deklica 'a sleeping girl', trepetajoče srce 'a trembling heart'. This use is not preserved in the dialects, however; it was rare even in the sixteenth century texts (Tomšič 1955: 58), except for a few old participial forms in -čc, devoid of such verbal categories as aspect, voice, taxis, and concord. These forms function in slovene (as in other Slavic languages) as simple adjectives, e.g., vroč ' hot', rdeč 'red', sloveč 'famous', or as adverbs, e.g., rekoč, gredoč.

4 Metelko 1825:231 used the term transgressivus, Svane 1958:75 - Präsenstransgressiv, Lencek 1966:30 - present-adverb, Toporišič 1967-167 - deležje.

5 In the following corpus of Examples, the examples within the context (1)-(10), (52)-(57), are given separately from the entries in the BdC Mss: (11)-(51). The entries appear as they are recorded in the adduced sources. Where provided, the recorder's translation and commentary are also given. The numbers following the abbreviations "BdC 1895", and "BdC 1904", refer to the entries, the numbers after "Merkù 1976", to the pages in these collections. The place names are quoted after Medved 1974; a Slavic name is followed by its Italian equivalent. Our glosses appear between single quotation marks '...'; the interpretations in quoted material are added in square brackets $[\ldots \ldots \ldots]$.

\section{Povzetek \\ RABA GERUNDIJA SEDANJEGA ČASA V SLOVENSKIH GOVORIH V KONTAKTU S FURLANŠC̆INO}

Članek prinaša novo gradivo Jana Baudouina de Courtenay o oblikah gerundija sedanjega časa na - $-\check{\mathrm{v}}$ slovenskih terskih in rezijanskih govorih in analizira njihovo sintaktično rabo. Zaključki analize so sledeči:

1. Od treh osnovnih sintaktičnih zvez v gradivu (BdC 1895, BdC 1904, BdC Mss) dve odražata gerundialne konstrukcije slovenskih tekstov starejših obdobij; 
pri eni gre za apozicionalno rabo gerundija ob predikatu (tip: Otroci so hodili pojoč), pri drugi za predikativno rabo gerundija po glagolih zaznavanja (tip: *Slišim otroke pojoč). Ena sama gerundialna zveza $\mathrm{v}$ terskih govorih predstavlja idiomatsko konstrukcijo, izposojeno neposredno iz italijanščine (primer: kxoo xódite díluc, It. : che cosa andate facendo).

2. Ker je gerundialna raba $\mathrm{v}$ retoromanskih dialektih(in $\mathrm{v}$ romanskih jezikih nasploh) raznoličnejša in veliko pogostnejša kot $v$ slovenščini, bi se zdelo, da gre $\mathrm{v}$ pogostnejši rabi gerundija $\mathrm{v}$ slovenskih zapadnih govorih za sledove direktne gramatične interference ob kontaktu dveh različnih jezikovnih območij. Ob primerjavi s starejšim stanjem $\mathrm{v}$ slovenskih tekstih šestnajstega stoletja, ki verjetno odražajo gerundialno rabo slovenskih centralnih govorov svoje dobe, pa se zdi, da gre preje za poseben primer "mešanja morfološkega vpliva", ki ga avtor pojasnjuje tako-le:

3. Denimo, da imata dva jezika $v$ kontaktu (jezika $A$ in $B$ ) na neki stopnji razvoja nekaj istih gramatičnih kategorij, ekvivalentne morfeme in analogne sintaktične vzorce, in da $\mathrm{v}$ svojem individualnem razvoju jezik $\mathrm{B}$ zgubi nekaj teh vzorcev, medtem ko jih dialekti jezika $\mathrm{B}$, $\mathrm{ki}$ so $\mathrm{v}$ kontaktu $\mathrm{z}$ jezikom $\mathrm{A}$, ohranijo. Pri take vrste gramatıčni interferenci ne gre za enostaven prenos morfemov kot takih ali njihovih kombinacij $\mathrm{v}$ prevodu iz jezika $\mathrm{A} v$ dialekte jezika $\mathrm{B}$. Tu gre za ohranjanje ali celo za ojačevanje predobstoječih funkcij ekvivalentnih morfemov $\mathrm{v}$ obeh jezikih, $\mathrm{v}$ našem primeru - $\mathrm{v}$ zapadnoslovenskih govorih po sintaktičnih vzorcih furlanščine in italijanščine. Ta tip jezikovne interference $\mathrm{v}$ slovenskih govorih doslej še ni bil registriran. 